$12-2016$

\title{
Book Review: Women and War in Rwanda: Gender, Media and the Representation of Genocide
}

Sara E. Brown

San Diego State University

Follow this and additional works at: https://digitalcommons.usf.edu/gsp

\section{Recommended Citation}

Brown, Sara E. (2016) "Book Review: Women and War in Rwanda: Gender, Media and the Representation of Genocide," Genocide Studies and Prevention: An International Journal: Vol. 10: Iss. 3: 95-97.

DOI:

http://doi.org/10.5038/1911-9933.10.3.1448

Available at: https://digitalcommons.usf.edu/gsp/vol10/iss3/11

This Book Review is brought to you for free and open access by the Open Access Journals at Digital Commons @ University of South Florida. It has been accepted for inclusion in Genocide Studies and Prevention: An International Journal by an authorized editor of Digital Commons @ University of South Florida. For more information, please contact digitalcommons@usf.edu. 


\author{
Sara E. Brown \\ San Diego State University \\ San Diego, CA, USA
}

Women and War in Rwanda: Gender, Media and the Representation of Genocide

Georgina Holmes

London \& New York, I.B. Tauris, 2014

304 Pages; Price: \$110.00 Cloth

Reviewed by Sara E. Brown

San Diego State University

Women and War in Rwanda is a useful addition to the ongoing conversation about the role of media and the genocide in Rwanda. This book also adds a welcome and key feminist perspective that is often absent from otherwise impressive scholarship on the genocide in Rwanda.

Using discourse analysis, Women and War in Rwanda examines the BBC narrative (comprised of two programs, Panorama and Newsnight, and the BBC website) of Rwanda and the east of Congo and examines "the way in which Rwandan and Congolese women were seen to perform in war and genocide" between 1994 and 2010. ${ }^{1}$ This book endeavors to challenge the existing gendered lens by rejecting an essentialist reading of women's experiences and reality as uniform. According to Holmes, this lens perpetuated in part by feminists, depicts African women as passive, agency-less victims during conflict. First analyzing the imaging of women in Rwanda during and following the genocide, the book concludes with an analysis of international (comprised of governments, media, and non-governmental and inter-governmental organizations) depictions of mass rape and genocide by attrition in the Democratic Republic of the Congo (referred to as Congo). Holmes argues broadly that "mediatized political discourse" about the Great Lakes region of Central Africa "has been produced and sustained" by an array of political and non-political actors with varying agendas and that women play a central role, particularly in the gendered international politics of revisionism. ${ }^{2}$

The first chapter "Contextualizing media events: war and genocide in Rwanda and the east of Congo" emphasizes the chronology of events preceding, during, and following the genocide in Rwanda. A rushed but concise history of the genocide in Rwanda then segues to a history of the 1996 and 1998 wars in east Congo before returning to Rwanda immediately post-genocide. Throughout the chapter, Holmes details the events and layers of context that underpin the 1994 genocide in Rwanda and wars in east Congo. It is an ambitious but dense chapter that introduces many interesting insights but may be difficult to follow for scholars new to Rwanda and the Great Lakes region.

The second chapter "Rwandan women and war" outlines a theoretical lens grounded in feminist theory and informed by political science as well as genocide and media studies. This interdisciplinary lens serves as the foundation, through agreement or disagreement, for Holmes's analysis and the author introduces several mini case studies to explain the broader narratives and "politics of revisionism" in Rwanda and east Congo. The literature that underpins the author's analysis is expansive and offers a unique lens for examination of the book's primary case studies.

Chapter three, "Militarizing women, preparing for genocide: Hutu extremist magazine Kangura 1990-94," offers a brief history of the democracy movement in pre-genocide Rwanda and a case study analysis of Kangura, an extremist publication widely acknowledged by scholars and Rwandans alike for its role in fomenting genocide in Rwanda. Holmes asserts that Kangura's images and publications militarized and imaged Rwandan women according to their ethnicity and citizenship status. Holmes divides her analysis into three key parts that she supports with

\footnotetext{
${ }^{1}$ Georgina Holmes, Women and War in Rwanda: Gender, Media, and the Representation of Genocide (London \& New York: I.B. Tauris, 2014), 3 .

${ }^{2}$ Ibid., 3.

Jeffrey Blustein, "Book Review: Women and War in Rwanda: Gender, Media and the Representation of Genocide" Genocide Studies and Prevention 10, 3 (2016): 95-97. @2016 Genocide Studies and Prevention.

http://dx.doi.org/10.5038/1911-9933.10.3.1448
} 
examples from the print periodical: non-citizen Rwandan women (Tutsi), full-citizen Rwandan women (Hutu), and partial citizen Rwandan women (Hutu but ostracized for political actions). Holmes details the fate of specific women who embody the last two groups of women which helped to further illustrate their status and fate in 1994 Rwanda.

The fourth chapter "Newsnight," examines the role of one BBC television program that offered political news coverage in 1994 and was considered reputable, "deemed an essential component of British democracy." ${ }^{3}$ Holmes argues that scholars too often focus on media's influence on government policy and not the government's influence on media and news creation. The chapter first analyzes the frequency and content of Newsnight's coverage of the genocide in Rwanda, briefly explores how Newsnight mediatized Rwandan women, and then examines how the various actors in Rwanda and east Congo maneuvered the media to advance their version of history and "truth." This chapter provides necessary historical and political context to the narratives propagated by $\mathrm{BBC}$ programs in both conflicts.

Chapter five "Remembering genocide, forgetting politics: the BBC's institutional narrative post1994," examines the push/pull of BBC efforts to document the 1994 genocide and simultaneously obfuscate the UK's role and foreign policy decision making during that period. This chapter offers unique insight into BBC institutional history, examining how the media outlet's narrative of the genocide in Rwanda, from Newsnight news features to Panorama documentaries and docu-dramas, shifted over time and in accordance with the "changing industry environment and political climate within which the BBC operated from 1994 onwards." ${ }^{\prime 4}$ It also questions the institutional independence of the $\mathrm{BBC}$, offering evidence that its programming was influenced by both British and Rwandan governments.

Chapter six, "'Living on gold should be a blessing, instead it is a curse': mass rape in the Congo," transitions to the wars in east Congo that followed the end of the genocide in Rwanda and uses graphic testimony and evidence from various reports, articles, and documentaries to make the case for the existence of "genocide by attrition" in east Congo and "mass rape" as part of the process of genocide by attrition. ${ }^{5}$ Holmes critiques the "western feminist legacy," human rights bodies, and the media for asserting that all women are victims in east Congo and all men are perpetrators. This salient critique exposes a paradigm that leaves little room for an inclusive discussion and ignores women who perpetrate and men and boys who are victims.

Holmes correctly critiques Newsnight in Chapter six for imaging violence in the Democratic Republic of the Congo as a continuation of the genocide in Rwanda. While the violence in the east of Congo is connected in part to the 1994 genocide, each conflict has distinct origins, impacts, and realities, especially for women. At the same time, this book, consciously titled Women and War in Rwanda, risks a similar imaging issue. The final chapter, dedicated to east Congo due to its proximity to Rwanda and the spillover of the genocide into Congo, and analyzing the imaging of women across both conflicts as its weft thread, risks conflating the two conflicts into one.

This book does an excellent job examining the "mediatized political discourses" produced and sustained by the media and an array of political and non-political actors. As a gender analysis, it examines the masculinization and feminization of war and genocide, but in several sections analysis of women in particular seems to be an afterthought, inserted after the initial analysis rather than at its core. In the first chapter, while women are repeatedly mentioned in topic sentences, the subsequent paragraphs often transition to an almost entirely male-centric analysis. While this constitutes a gender analysis that addresses male-centric narratives, it belies the title and expressed intent of this book. This may be due in part to the existing lacunae in the literature, but such gaps also provide an opportunity which the author overlooks in this section. In addition, in the fifth chapter, while brief sections address the feminization of victims and mediatizing genocidal rape in Rwanda, the emphasis is clearly placed on the broader institutional history of the BBC and its narrative impact on coverage of Rwanda.

\footnotetext{
${ }^{3}$ Ibid., 130 .

${ }^{4}$ Ibid., 178 .

${ }^{5}$ Ibid., 225.
} 
Overall, for scholars interested in a history and analysis of the BBC's coverage of Rwanda, this book is a must-read. And for those interested in a gender analysis of the media and coverage of women in Rwanda and east Congo, this book serves as a welcome addition to a developing conversation. 